\title{
Analysis of deaths due to acquired immunodeficiency syndrome
}

\author{
Análise de óbitos por síndrome da imunodeficiência adquirida
}

Katia Barbosa Franco ${ }^{1}$, Gilmara Holanda da Cunha ${ }^{1}$, Maria Amanda Correia Lima ${ }^{1}$, Dalila Augusto Peres ${ }^{1}$, Marli Teresinha Gimeniz Galvão ${ }^{1}$, Reângela Cintia Rodrigues de Oliveira Lima ${ }^{1}$

Objective: to analyze the profile of the deaths of people with acquired immunodeficiency syndrome. Methods: a cross-sectional study was carried out with 106 medical records of people who died in an intensive care unit, obtaining sociodemographic and clinical variables. Analysis made using Pearson's chi-square test, Fisher's test and Mann-Whitney test. Results: most of the patients were male (80.2\%), in the age group from 18 to 39 years, average age of 39.7 years, $81.6 \%$ dark-skinned, $60.4 \%$ were single and $62.5 \%$ unemployed. The proportion of patients who were unemployed $(\mathrm{p}=0.002)$ and who did not use antiretroviral therapy $(\mathrm{p}<0.001)$ were the ones that had the least regular health care. Conclusion: most of the patients in the study did not follow regular health care and did not use antiretroviral therapy.

Descriptors: Acquired Immunodeficiency Syndrome; Death; Health Promotion.

Objetivo: analisar o perfil dos óbitos de pessoas com síndrome da imunodeficiência adquirida. Métodos: estudo transversal, realizado com 106 prontuários de pessoas que foram a óbito em unidade de terapia intensiva, obtendo-se variáveis sociodemográficas e clínicas. Análise realizada através do teste qui-quadrado de Pearson, teste de Fisher e teste de Mann-Whitney. Resultados: maior parte dos pacientes era do sexo masculino (80,2\%), na faixa etária de 18 a 39 anos, média de idade de 39,7 anos, $81,6 \%$ de cor parda, $60,4 \%$ solteiros e $62,5 \%$ desempregados. A proporção de pacientes desempregados $(\mathrm{p}=0,002)$ e que não faziam uso de terapia antirretroviral $(p<0,001)$ foram os que menos realizavam acompanhamento regular de saúde. Conclusão: a maioria dos pacientes do estudo não realizava acompanhamento regular de saúde e não utilizava terapia antirretroviral.

Descritores: Síndrome de Imunodeficiência Adquirida; Morte; Promoção da Saúde.

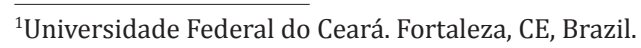




\section{Introduction}

Acquired immunodeficiency syndrome (AIDS) is a disease that causes several complications to health, representing in terms of control and treatment a challenge to public health ${ }^{(1)}$. From the beginning of its epidemic, until the year 2014, there were 290,929 AIDS deaths in Brazil, but in general, there is a decline in mortality ${ }^{(2)}$. This is due to the introduction of antiretroviral therapy, which in Brazil has been available free of charge since $1996^{(3)}$. However, the reduction of AIDS deaths did not happen equally among the Brazilian regions, since in the Northern and Northeastern regions mortality growth is still observed ${ }^{(2)}$.

Initially, management of human immunodeficiency virus (HIV) infection, the causative agent of AIDS, was performed in patients with advanced stages of the disease, which required complex therapeutic options. Currently, it has been observed that patients are more stable and using simplified therapeutic regimens, which is similar to the care of patients with chronic diseases. Therefore, it is understood that different levels of need require specific intervention at different levels of attention ${ }^{(4)}$.

Health care for people living with HIV/AIDS does not occur in a universal and egalitarian way in Brazil. This causes difficult access to diagnosis and, consequently, late onset antiretroviral therapy ${ }^{(4)}$. The difficulty in accessing health services for counseling, testing, treatment and disease prevention actions is a factor that influences the quality of this assistance in a relevant way. These aspects may also increase the severity of these patients' health status and even death from AIDS ${ }^{(5-6)}$.

Thus, it is important to elaborate interventions aimed at improving care in the diagnosis, treatment and prevention of HIV/AIDS at the primary, secondary and tertiary levels of health care ${ }^{(6)}$. And in order for health professionals to be able to respond to the challenges posed and contribute to a reduction in the number of deaths due to AIDS, answers to the following questions become relevant: What is the sociode- mographic and clinical profile of patients who died of AIDS?

In this context, considering that the care of people living with HIV/AIDS is the responsibility of the nurse and other members of the health team, health promotion strategies are necessary, based on the analysis of AIDS deaths, So that professionals can deal with the factors that influence these deaths and can improve the quality of life of people with AIDS, contributing to the reduction of AIDS deaths. In view of the above, this study aimed to analyze the profile of the deaths of people with acquired immunodeficiency syndrome.

\section{Methods}

This is an exploratory cross-sectional study. The research was held in a hospital in Fortaleza, Ceará, Brazil. That institution is a state reference for the treatment of infectious diseases and has actions and services for the follow-up of HIV/AIDS infection for users of the Unified Health System.

The study population consisted of the records of people who died of AIDS at the hospital between January and December 2015, who met the inclusion and exclusion criteria $(n=106)$. The inclusion criteria were: records of people of both sexes, who died as a basic cause of AIDS, and aged 18 years or older. The exclusion criterion was death in which the medical record was not available during the period of data collection.

Data were collected between March and May 2016. Secondary data were used for data collection. Initially, a search was made in the Mortality Information System to identify the deaths occurring in the hospital. The patients' records were searched, whose variables of interest for the study were: gender, age, race, schooling, time of diagnosis, use of antiretroviral therapy and follow-up. For this collection, the Protocol for the investigation of deaths by HIV/AIDS was used $^{(7)}$.

The data were analyzed using the Software Sta- 
tistical Package for the Social Sciences ${ }^{\circledR}$ version 22.0. The sociodemographic and clinical characteristics were arranged through descriptive statistics, through frequency distributions, average, median and standard deviation. The association between the variables was tested using the Pearson chi-square test. Fisher's test and the Mann-Whitney test were used to test the comparison between the groups. The significance level adopted was $5.0 \%$, considering a statistically significant value of $\mathrm{p} \leq 0.05$.

The study complied with the formal requirements contained in national and international standards for research involving human subjects.

\section{Results}

After analyzing the data, it was observed that the majority of people who died were male (80.2\%), aged between 18 and 39 years (53.8\%), brown (81.6\%), (53.5\%), unmarried $(60.4 \%)$ and unemployed (62.5\%) (Table 1). It should be noted that some information was not described in its completeness in the medical record, thus, the number of patients in the variables analyzed was specified in the table.

Table 1 - Sociodemographic characterization of people who died of AIDS

\begin{tabular}{lc}
\hline Sociodemographic variables & n (\%) \\
\hline Sex (n=106) & $85(80.2)$ \\
$\quad$ Male & $21(19.8)$ \\
Female & \\
Age range (years)* (n=106) & $57(53.8)$ \\
$18-39$ & $43(40.6)$ \\
$40-59$ & $6(5.6)$ \\
$\geq 60$ & \\
Skin color (n=103) & $84(81.6)$ \\
Dark-skinned & $19(18.4)$ \\
Not dark-skinned & \\
Schooling (years) (n=101) & $11(10.9)$ \\
$\quad$ No schooling & $54(53.5)$ \\
$1-8$ & $36(35.6)$ \\
$\geq 9$ & $64(60.4)$ \\
Marital status (n=106) & $32(30.2)$ \\
Single & $10(9.4)$ \\
Married/living together/ unmarried unions/lovers & \\
Divorced/separated/widow & $36(37.5)$ \\
Occupational status (n=96) & $60(62.5)$ \\
$\quad$ Employed/retired/social security beneficiary \\
Unemployed
\end{tabular}

Regarding the clinical characteristics, it was observed that $48.1 \%$ of the individuals did not use antiretroviral therapy before death and the majority had not started regular follow-up in health services (59.4\%). Regarding the time of diagnosis of HIV positive patients at the time of death, an average of five months (25: 1 percentile, 75: 72 percentile) was recorded (Table 2). Regarding the CD4 + T lymphocyte count and plasma viral load, only 26 patients (24.5\%) who died of AIDS had undergone these tests. The average CD4 + T lymphocyte counts were 309.8 cells $/ \mathrm{mm}$ 3 and the viral load was 70.3 copies $/ \mathrm{ml}$.

Table 2 - Clinical characterization of people who died of AIDS

\begin{tabular}{lc}
\hline Clinical variables & n (\%) \\
\hline Use of antiretroviral therapy $(\mathrm{n}=106)$ & $55(51.9)$ \\
Yes & $51(48.1)$ \\
No & \\
Assistance in health service $(\mathrm{n}=106)$ & $38(35.8)$ \\
Yes & $63(59.4)$ \\
No & $5(4.8)$ \\
No information & \\
Time of diagnosis (months)* $(\mathrm{n}=95)$ & $53(55.8)$ \\
$<12$ & $12(12.6)$ \\
$12-60$ & $30(31.6)$ \\
$>60$ &
\end{tabular}

Associations were made between the variables gender, age, skin color, schooling, occupational situation and use of antiretroviral therapy with the regular monitoring variable in health services. It was found that the proportion of unemployed who did not have follow up on health was significantly higher than that of the employed who did not follow health care $(p=0.002)$. A higher proportion of patients who did not use antiretroviral therapy also did not have regular follow-up in the health service $(\mathrm{p}<0.001)$ (Table 3$)$.

Concerning the time variable it was considered median. 84 months (percentile 25: 42; percentile 75: 120 ) for those patients who had regular follow-up at the health service, and one month (percentile 25: 0.3; percentile 75: 4) for those who did not have health monitoring $(\mathrm{p}<0.001)$ (Mann-Whitney test). Thus, pe- 
ople with AIDS who died most were those who were not being followed regularly in health service, and therefore, died despite the short time of diagnosis of HIV positive serology.

Table 3 - Association between sociodemographic and clinical variables with regular follow-up in health services

\begin{tabular}{|c|c|c|c|}
\hline \multirow{2}{*}{ Variables } & \multicolumn{2}{|c|}{$\begin{array}{c}\text { Regular assistance in } \\
\text { health service }\end{array}$} & \multirow{2}{*}{$\mathbf{p}$} \\
\hline & $\begin{array}{c}\text { Yes } \\
\text { n (\%) }\end{array}$ & $\begin{array}{c}\text { No } \\
\text { n (\%) }\end{array}$ & \\
\hline Sex $(n=101)$ & & & $0.607^{1}$ \\
\hline Male & $32(39.5)$ & $49(60.5)$ & \\
\hline Female & $6(30.0)$ & $14(70.0)$ & \\
\hline Age range (years) $(n=101)$ & & & $0.058^{2}$ \\
\hline $18-39$ & $16(28.5)$ & $40(71.5)$ & \\
\hline $40-59$ & $19(46.4)$ & $22(53.6)$ & \\
\hline$\geq 60$ & $3(75.0)$ & $1(25.0)$ & \\
\hline Skin color $(\mathrm{n}=101)$ & & & $0.431^{1}$ \\
\hline Dark-skinned & $29(35.4)$ & $53(64.6)$ & \\
\hline Not dark-skinned & $9(47.3)$ & $10(52.7)$ & \\
\hline Schooling (years) $(\mathrm{n}=96)$ & & & $0.181^{2}$ \\
\hline No schooling & $1(10.0)$ & $9(90.0)$ & \\
\hline $1-8$ & $21(40.4)$ & $31(59.6)$ & \\
\hline$\geq 9$ & $13(38.2)$ & $21(61.8)$ & \\
\hline Occupational status (n=92) & & & $0.002^{1}$ \\
\hline $\begin{array}{l}\text { Employed/retired/ social security } \\
\text { beneficiary }\end{array}$ & $22(61.1)$ & $14(38.8)$ & \\
\hline Unemployed & $15(26.7)$ & $41(73.2)$ & \\
\hline Use of antiretroviral therapy $(n=101)$ & & & $0.001^{1}$ \\
\hline Yes & $35(70.0)$ & $15(30.0)$ & \\
\hline No & $3(5.9)$ & $48(94.1)$ & \\
\hline
\end{tabular}

\section{Discussion}

According to this study, researches indicate a higher frequency of AIDS deaths in young and male adults, mainly affecting the age groups of 20-24 and between 30 and 44 years $^{(2,8-9)}$. Likewise, in the year 2014, the proportional distribution of deaths by aids according to race/color showed a higher prevalence among dark-skinned people ${ }^{(2)}$. AIDS mortality in Brazil has been significantly reduced since the beginning of the epidemic, attributed mainly to the use of antiretroviral therapy in the treatment of the disease. However, it should be noted that other factors are also relevant to this fact, such as preventive actions and health promotion ${ }^{(8)}$.
Therefore, as a proposal for intervention that contemplates preventive actions and health promotion, we have the use of a condom that is effective against the transmission of HIV. However, many people often associate their use with partner infidelity. One factor directly associated with the non-use of condoms is the relationship with fixed partners, due to the inability to negotiate between them, mainly on the part of the women, who fear the partner's attitudes and submit to the will of the partner ${ }^{(10)}$.

In addition, the lack of female condom disclosure and its high cost as influencers for its low use among women ${ }^{(11-13)}$ are noteworthy. It is also worth noting that the combination of different health interventions tends to increase condom adhesion, such as participation in support groups and discussion of strategies to promote condom use and mobilization through dialogue between the couple and freedom of expression $^{(14)}$.

It was found that people living with HIV/AIDS who were unemployed were the ones who died the most and did not perform regular follow-up on health services. It has been shown that schooling and occupation are markers of the socioeconomic conditions of people living with HIV/AIDS ${ }^{(15)}$. The study shows that low educational level and lower income may reflect the lack of access to diagnosis and treatment of the disease, converging to increase unequal mortality among people of different economic levels ${ }^{(8)}$.

Thus, the spread of AIDS among people with low schooling and unemployed points to a susceptibility, possibly due to lack of information and less access to means of prevention. In order to achieve a higher quality of health care and prevention, it is necessary that information be passed on continuously and in a language that is easy to understand. The nurse, as a health professional, acts as a facilitator, acting through the implementation of educational or informational interventions, in order to explain the importance of prevention, transmission and improvement of HIV/ AIDS follow-up and treatment ${ }^{(16)}$.

An important factor for improving the follow- 
-up of patients with HIV/AIDS and for better prognosis of the disease is the time of diagnosis of the infection, because the late diagnosis facilitates the discovery of the disease in advanced stages, besides influencing the cause of AIDS deaths and mortality rate growth.

Programmatic interventions such as the opening of specialized health centers, the provision of rapid HIV testing, decentralization of actions and expanded access to the serological diagnosis of infection are essential for the early diagnosis of HIV infection. These actions make it possible to improve the quality of life of people with HIV/AIDS, reduce the mortality associated with AIDS and the transmission of the disease. It is also necessary to identify the groups most vulnerable to HIV in terms of acquisition of infection and risk of illness ${ }^{(17)}$.

Regarding the abandonment of treatment by the HIV/AIDS patient and the regular monitoring in health services, the risk of abandonment was observed in single people, mainly in the initial phase of the disease, when they need a social support network, which is the responsibility of the family, friends and health staff( ${ }^{(18)}$.

Follow-up of the disease also involves laboratory tests, such as CD4 + T lymphocytes count and plasma viral load, which aim at monitoring the effectiveness of antiretroviral therapy, observing suppression of viral load, prevention of viral resistance and failure of therapy, as well as reducing AIDS morbidity and mortality, making it possible to increase the survival of people living with HIV/AIDS ${ }^{(19)}$.

In addition, health monitoring is essential to diagnose other sexually transmitted infections, which can be identified by the syndrome approach, aiming at the prevention of complications, sequelae and breakdown of the transmission chain ${ }^{(20)}$. The use of antiretroviral therapy and the health monitoring of individuals with HIV/AIDS are interrelated, since the patient who is using antiretroviral drugs, in order to have an adequate follow-up of the treatment, needs to maintain a bond with the health services. Therefore, adhesion is also related to the characteristics of the organization of care in health services, with emphasis on the availability of resources, infrastructure, conditions of care and elaboration of actions aimed at improving adhesion ${ }^{(18,20)}$.

The actions to strengthen the adhesion of people living with HIV/AIDS to antiretroviral therapy and to maintain the patient in health monitoring are fundamental aspects for the management of the disease and the achievement of therapeutic success. However, in addition to the individual health interventions aimed at the effectiveness of this maintenance, it is important that there is an impact on the dissemination of the disease in the collective plan in the different health services.

Adhesion to treatment is a determinant in improving quality of life and decreasing mortality rates, but it is one of the greatest challenges of care for patients with HIV/AIDS. This is due to the diverse demands of users, to behavioral and dietary changes, to the use of various medications throughout their lives, and to the need for new services and offer of specific activities in adhesion ${ }^{(15,20)}$.

The participation of health professionals, among them nurses, in the population's awareness for the early diagnosis of HIV infection and in the implementation of public health measures are important to reduce the transmission of the virus. Increased supply and ease of access to serological testing are interventions aimed at reducing the failure of disease management by responsible health services, implying a favorable prognosis for HIV infection and reducing the progression of disease and death.

However, it is worth mentioning that all health professionals should be aware of the registration of information regarding the care provided to patients, because as a limitation of this study there was inadequate completion of medical records or omission of information. Thus, it is necessary to guide the health team regarding the correct filling of patients' data, both at the time of admission and in hospital stay. New research is suggested that implement interventions aimed at reducing risk factors for death among people 
living with HIV/AIDS, and that the impact of these studies be evaluated in the long term.

This study evidenced gaps in the care given to these patients, regarding health promotion practices. As a result, there is a need for interventions to improve the diagnosis, follow-up and treatment, in order to reduce the complications inherent to the therapeutic failure, promoting quality of life and, consequently, reducing the occurrence of death due to AIDS.

\section{Conclusion}

The analysis of the profile of the deaths of people with AIDS showed that these subjects were in the age range from 18 to 39 years, were unemployed, did not use antiretroviral therapy, and those with less time of diagnosis were those who had less regular services of health. Thus, most of the patients in the study did not follow regular health care and did not use antiretroviral therapy.

\section{Collaborations}

Franco KB, Cunha GH, Lima MAC, Peres DA, Galvão MTG and Lima RCRO contributed to the project design, data analysis and interpretation, article writing, critical review of the intellectual content and final approval of the version to be published.

\section{References}

1. Ministério da Saúde (BR). Secretaria de Vigilância em Saúde. Departamento de DST, Aids e Hepatites Virais. Boletim Epidemiológico - Aids e DST. Ano IV, no 01, 27aa à 53aㅡ semana epidemiológica - julho a dezembro de 2014 e $01^{\text {a }}$ à $26^{\underline{a}}$ semana epidemiológica - janeiro a junho de 2015. Brasília: Ministério da Saúde; 2015.

2. Teixeira TRA, Gracie R, Malta MS, Bastos FI. Social geography of AIDS in Brazil: identifying patterns of regional inequalities. Cad Saúde Pública. 2014; 30(2):259-71. doi: http://dx.doi. org/10.1590/0102-311X00051313
3. Paschoal EP, Santo CCE, Gomes AMT, Santos EI, Oliveira DC, Pontes APM. Adherence to antiretroviral therapy ant its representatios for people living with HIV/AIDS. Esc Anna Nery. 2014; 18(1):32-40. doi: http://dx.doi. org/10.5935/1414-8145.20140005

4. Assis MMA, Jesus WLA. Acesso aos serviços de saúde: abordagens, conceitos, políticas e modelo de análise. Ciênc Saúde Coletiva. 2012; 17(11):2865-75. doi: http://dx.doi.org/10.1590/ S1413-81232012001100002

5. Macedo LM, Martin STF. Interdependência entre os níveis de atenção do Sistema Único de Saúde (SUS): significado de integralidade apresentado por trabalhadores da Atenção Primária. Comunic Saúde Educ. 2014; 18 (51):647-59. doi: http:// dx.doi.org/10.1590/1807-57622013.0597

6. Alves RH, Reis DC, Viegas AM, Neves JAC, Almeida TAC, Flisch TMP. Perfil epidemiológico da AIDS em contagem, Minas Gerais, Brasil, entre 2007 e 2011. Rev Epidemiol Control Infect. 2015; 5(3):147-52. doi: http://dx.doi.org/10.17058/reci.v5i3.5745

7. Ministério da Saúde (BR). Protocolo de investigação de óbito por HIV/aids [Internet]. 2014 [citado 2016 jul. 10]. Disponível em: http:// www.aids.gov.br/sites/default/files/anexos/ publicacao/2014/56593/_p_protocolo_de_ investigacao_de_obitos_por_aids_p_23585.pdf

8. Antunes JLF. Intervenções em saúde pública e seu impacto nas desigualdades sociais em saúde. Tempo Soc. 2015; 27(1):162-75. doi: http:// dx.doi.org/10.1590/0103-20702015018

9. Traebert J, Silva MF, Nickel DA, Schneider IJC. Estimativa da carga de doença por aids em Florianópolis, Santa Catarina, Brasil, 2009. Epidemiol Serv Saúde. 2015; 24(3):517-22. doi: http://dx. doi.org/10.5123/S1679-49742015000300017

10. Harrison A, Colvin CJ, Kuol C, Swartz A, Lurie M. Sustained high HIV incidence in young women in southern Africa: social, behavioral and structural factors and emerging intervention approaches. Curr HIV/AIDS Rep. 2015; 12(2):207-15. doi: http://dx.doi.org/10.1007/s11904-015-0261-0 
11. Valim EMA, Dias FA, Simon CP, Almeida DV, Rodrigues MLP. Utilização de preservativo masculino entre adolescentes de escolas públicas na cidade de Uberaba (MG), Brasil: conhecimentos e atitudes. Cad Saúde Coletiva. 2015; 23(1):44-9. doi: http:// dx.doi.org/10.1590/1414-462X201500010008

12. Pinheiro TF, Calazans GJ, Ayres JRCM. Uso de camisinha no Brasil: um olhar sobre a produção acadêmica acerca da prevenção de HIV/Aids (2007-2011). Temas Psicol. 2013; 21(2):81536. doi: http://dx.doi.org/10.9788/TP2013.3EE07PT

13. Oliveira SA, Moura CB, Calgaro M, Torres SL. Motivos do não uso do preservativo entre adolescentes de um município da tríplice fronteira. Rev Bras Educ Saúde [Internet]. 2014 [citado 2017 jun. 12]; 5(1):100-8. Disponível em: http://www.gvaa.com.br/revista/index.php/ REBES/article/view/2581/2837

14. Dourado I, MacCarthy S, Reddy M, Calazans G, Gruskin S. Revisiting the use of condoms in Brazil. Rev Bras Epidemiol. 2015; 18(1):6388. doi: http://dx.doi.org/10.1590/18094503201500050006

15. Lima TC, Freitas MIP. Caracterização de população com 50 anos ou mais atendida em serviço de referência em HIV/Aids, Brasil. Rev Ciênc Méd Campinas [Internet]. 2013 [citado 2017 jun. 06]; 22(2):77-86. Disponível em: http://periodicos. puc-campinas.edu.br/seer /index.php / cienciasmedicas/article/view/2129/1779
16. Reis RK, Melo ES, Galvão MTG, Gir E. Health education for patients with hiv/aids: a proposal for interdisciplinary intervention. Cienc Cuid Saúde. 2014; 13(3):402-10. doi: http://dx.doi. org/10.4025/cienccuidsaude.v13i3.21120

17. Abati PAM, Segurado AC. HIV testing and clinical status upon admission to a specialized health care unit in Pará, Brazil. Rev Saúde Pública. 2015; 49(16):1-8. doi; http://dx.doi.org/10.1590/ S0034-8910.2015049004625

18. Silva JAG, Dourado I, Brito AMD, Silva CALD. Factors associated with non-adherence to antiretroviral therapy in adults with AIDS in the first six months of treatment in Salvador, Bahia State, Brazil. Cad Saúde Pública. 2015; 31(6):1188-98. doi: http:// dx.doi.org/10.1590/0102-311X00106914

19. Bellenzani R, Nemes MIB, Paiva V. Comunicação profissional-paciente e cuidado: avaliação de uma intervenção para adesão ao tratamento de HIV/ Aids. Comunic Saúde Educ. 2013; 17(47):80334. doi: http://dx.doi.org/10.1590/180757622013.0051

20. Santos MA, Nemes MIB, Nasser ACA. Adherence intervention based on constructionist care approach: the health professionals' perspective. Temas Psicol. 2013; 21(3):651-73. doi: http:// dx.doi.org/10.9788/TP2013.3-EE02PT 